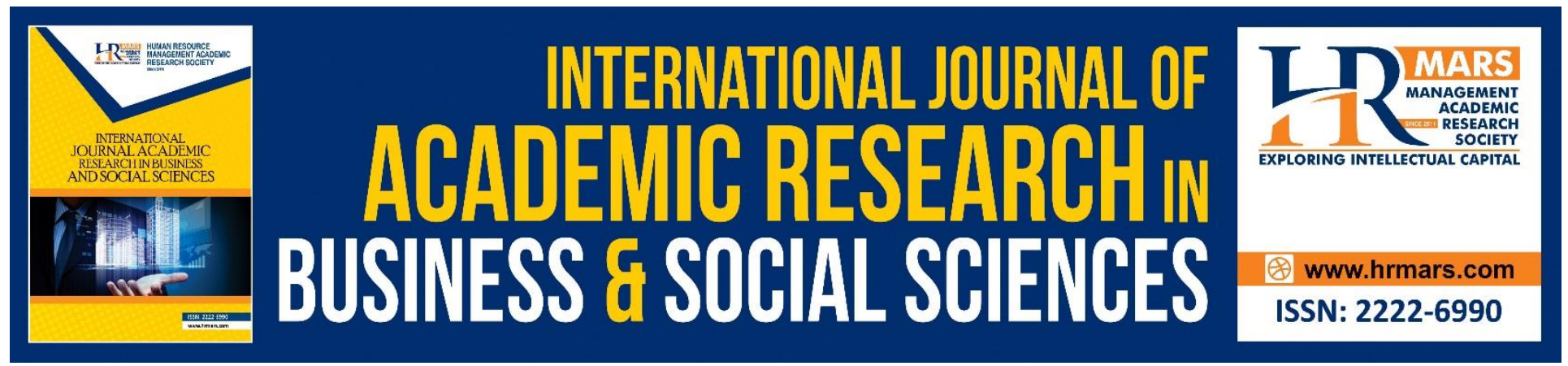

\title{
The Phenomenon of Terrorism and Its Remedy in the Light of the Values of Islamic Preaching
}

\author{
Moustafa Hassan Al-Khaiat \\ Firdaus Khairi Abdul Kadir
}

To Link this Article: http://dx.doi.org/10.6007/IJARBSS/v9-i2/5521 DOI: $10.6007 /$ IJARBSS/v9-i2/5521

Received: 04 Jan 2019, Revised: 23 Feb 2019, Accepted: 04 March 2019

Published Online: 05 March 2019

In-Text Citation: (Al-Khaiat \& Kadir, 2019)

To Cite this Article: Al-Khaiat, M. H., \& Kadir, F. K. A. (2019). The Phenomenon of Terrorism and Its Remedy in the Light of The Values of Islamic Preaching. International Journal of Academic Research in Business and Social Sciences, 9(2), 48-61.

\section{Copyright: (C) 2019 The Author(s)}

Published by Human Resource Management Academic Research Society (www.hrmars.com)

This article is published under the Creative Commons Attribution (CC BY 4.0) license. Anyone may reproduce, distribute, translate and create derivative works of this article (for both commercial and non-commercial purposes), subject to full attribution to the original publication and authors. The full terms of this license may be seen

at: $\underline{\text { http://creativecommons.org/licences/by/4.0/legalcode }}$

Vol. 9, No. 2, 2019, Pg. 48 - 61

http://hrmars.com/index.php/pages/detail/IJARBSS

JOURNAL HOMEPAGE

Full Terms \& Conditions of access and use can be found at http://hrmars.com/index.php/pages/detail/publication-ethics 


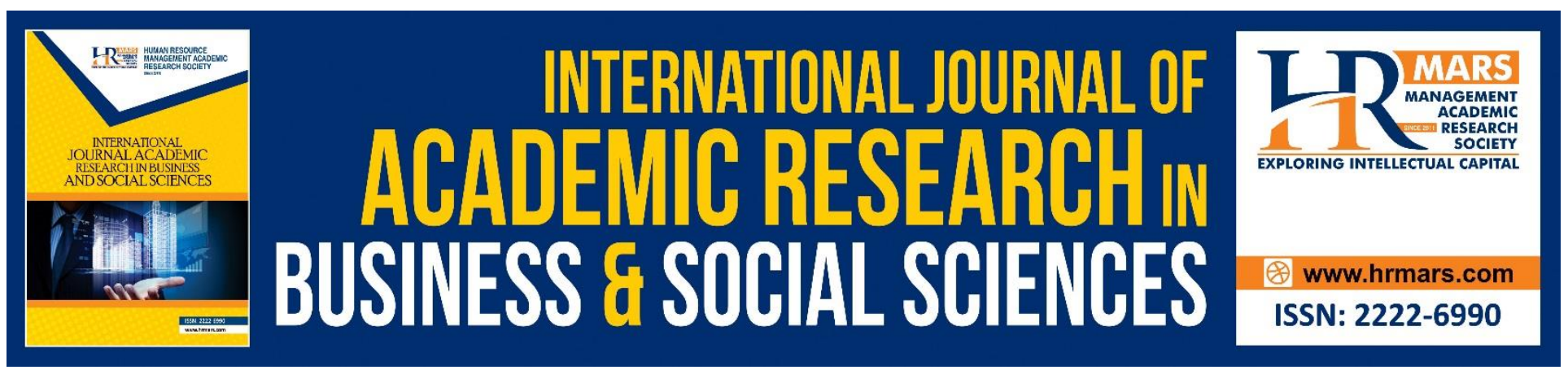

\title{
The Phenomenon of Terrorism and Its Remedy in the Light of the Values of Islamic Preaching
}

\author{
Moustafa Hassan Al-Khaiat \\ Faculty of Contemporary Islamic Studies, University of Sultan Zainal Abidin \\ Firdaus Khairi Abdul Kadir \\ Centre for Fundamental and Liberal Education, Universiti Malaysia Terengganu, Malaysia
}

\begin{abstract}
Terrorism represents a dangerous contemporary problem deeply rooted in history. Terrorism still forms, today, a great danger to different societies. This terrorism has its causes and the roots that gave rise to it. It has motives that made its protagonists freely allow themselves to do their terrorist actions, regardless of their effects on the lives of individuals and societies; politically, economically, as to security and psychologically. Due to non-Muslims' enmety to Islam, its vocation and its followers, they have been directing accusations of terrorism to Islam and Muslims; as soon as an incident takes place, all people hasten to direct accusations of terrorism against Islam and its mission, as well as Muslims and their faith. From the above discussion, we see the importance of the present research, which has attempted to define the concept of terrorism from the perspective of Islamic vocation and to study its causes and motives and how to face it in the light of the genuine values of Islamic preaching. All these values assert legal values and means and scientific tools(media) that assure for the society a life secure about souls, wealth and honor. The research has resulted in some important results and recommendations, including: asserting that Islamic mission or preaching is not part of the problem of terrorism ; rather it is a forceful basis and an effective tool to remedy its causes and putting an end to it according to the divine criteria through implanting the values of tolerant Islamic preaching. It is far from bigotry \{fanaticism\} and extremist interpretation that gives texts undue interpretations. Also the philosophy of Islamic vocation aims essentially at building a social structure caring for relating the individual to the society through solidarity, love and belonging in order to keep the stability of the society. Furthermore, terrorism cannot be ascribed only to the religious factor, for there are other factors which may be more important than the religious factor such as poverty, unemployment and misunderstanding the religious calling. Also the research proved that the phenomenon of terrorism is a western phenomenon rather than being related to Islam.
\end{abstract}

Keywords: Islamic Vocation, Terrorism, Values of Vocation. 


\section{Introduction}

This subject is significant for exposing the concept of terrorism and defining it from the view of Islamic preaching. Refutations and false concepts have been raised about Islamic vocation because of terrorist actions. That the West describes faithful Islamic movements as being terrorist movements. The role of the values of Islamic vocation in facing the phenomenon of terrorism. The subject's background and problem lie in the fact that terrorism represents a dangerous contemporary problem deeply rooted in history; for terrorism still forms, today, a great danger to different societies. Three questions arised; What is the concept of terrorism for the Western and for Muslims?, What are the causes of terrorism and its motives amongst societies?; and What are the values of vocation (preaching) for facing terrorism?

This article aimed at defining the concept of terrorism from the view of Islamic preaching, exposing the causes and motives of terrorism as well as showing the values of Islamic preaching for facing terrorism. The reasons for choosing this research are; The nonexistence of a clear definition of terrorism internationally agreed upon; The West's contradiction in the description of terrorism; for what conforms to their desires is not considered terrorism and what disagrees with them is considered terrorism; The problem of ascribing the concepts of to Islam and Muslims and finally Committing criminal actions by some Muslim individuals and governments, which deforms the image of Islam for non-Muslims.

\section{The Signification of terrorism from the view of the Islamic Worldview}

There has been a great confusion between the concepts of Islam and those of the Western culture, including the concept of terrorism, whose origin is Western, as the motive behind that is the forces hostile to Islamic vocation, its culture and its civilization. There has been an implanting of hateful concepts that have been stabilized in the Western atmosphere and rooted in its history. These have been symbols synonymous to barbarous and evil action. They have been related to some preaching concepts, such as the concepts of "jihad/fight" and "vocation" to further deform the image of Islam. However, we will clarify the concept of terrorism in Western and Arabic cultures and in the view of Islamic vocation.

\section{First: The Signification of Terrorism and Its Meaning for The Western Pespective}

The lexeme (terrorism) is considered a modern use arising from the Western propagation of the concept of a vague word, the meaning of which has not yet been specifically determined. Hence, there is a popular verb that says: "A terrorist for some people is, for another group, a struggler for freedom. "The electronic encyclopedia of Encarta defines" terrorism الارهاب" as "using violence or threatening for creating an atmosphere of panic among some people, targetting (at) some ethnic or religious groups, governments (regimes) or others. The English word (terrorism) is formed by adding the suffix "ism" or "izm" to the noun (terror), meaning fright, panic and horror. It also gives us the verb (terrorize), meaning to 
frighten or horrify. Hence, it is necessary to consider this subtle difference between the word الارهاب (threatening) and (الارعاب terrorism). Terrorism has a Latin origin.

\section{Second: The Signification of terrorism in Arabic Terrorism in Arabic}

The word ارهاب (terrorism /threatening) is derived from the verb ارهب, meaning: to frighten somebody. The verb رهب أر إن has the same meaning if the second letter is stressed or duplicated. However, the verb رهب رهب with an ordinary single هـ means (feared/felt afraid).

الرهبة means : fear and panic. However, the verb ترهب with a stressed or duplicated هـ means: 'be ascetic'. From it, is derived الراهب or monk. The same verb ارهب means: thean : theatened. The verb frighten or horrify somebody. The verb استرهب : اسهب has same meaning.(Ibn Manzoor, n.d.)

The word denotes a great degree of fear, horror and panic. So the word الارهاب instead of has to be used as a correct translation of (terrorism). However, they have been considered equal nowadays.

In a document edited in the Arab agreement for combatting terrorism, the following definition of terrorism was approved:" It is any action of violence or threatening with it, whatever were its motives or purpose denots, being done in carrying out a criminal scheme, individually or in a group, aiming at causing horror among people about their children or endangering their lives and safety. All instances and means of struggle are not considered crimes, including armed struggle against foreign occupation and hostilities for determining destiny according to the principles of international law." (alitfagiah al arabiah The Arab Convention for the Suppression of Terrorism, 1999)

\section{Third: The Signification of Terrorism in Islamic Vocation}

To understand the denotation of terrorism in Islamic vocation, it is a must to refer to its two main sources: The Qur'an and the prophet's tradition (Sunnah).

\section{The Signification of terrorism in The Qur'an}

The word 'terrorism' and its derivations were mentioned in The Qur'an. Here are some examples:

- Allah (Glory be to Him) said in Al-A'raf chapter154: "in its scripture, there is guidance and mercy for those who fear their God."

- Allah (Glory be to Him) said in Al-Baqarah (The Cow) chapter: 40." And keep your promise to me, so I will keep my promise to you and do fear me."

- Allah (Glory be to Him) said in Al-Nahl (The Bees) chapter: "Surely He is one God, so do fear me."

- (Glory be to Him) said in Al-A'raf chapter:116. "And they frightened them and performed a great magic." 
- Allah (Glory be to Him) said in Al-Anbia' (The Prophets) chapter:90 " And they pray to us out of wish and fear and were submissive to us".

In the previous verses of The Qur'an, we notice that the lexeme ترهبون (fear) has the meaning of fear of God and timidity before him, which is the means for Allah's contentment and deliverance both in the worldly life and in the afterlife.

The word الارهاب 'frightening' was mentioned in The Qur'an, about' frightening enemies and scaring them. Allah (Glory be to Him) said in Al-Anfal (The Spoils) chapter:60. "And prepare against them whatever force and chivalry you can manage to frighten by these the enemy of Allah and of yours, as well as others whom you don't know, but whom Allah knows. "This means to scare by these the enemy of Allah and of yours. The word frighten ترهبون does not denote 'terrorism' known these days, meaning panic, horror, destruction and ruin.

The word الارهاب 'frightening' in The Qur'an is meant to stop aggressors and frighten criminals as well as guiding people to the right path and preventing them from tyranny. This is a preventive action having a positive significance and similar to military repression. It is not related to 'terrorism' known these days, which means ruin, murder and destruction.

\section{Fourth: The Signification of Terrorism in The Prophet's Tradition (Sunnah)}

It is noticed that derivations (family) of the lexeme رهب/feared do not take place frequently in The Prophet's Hadith (sayings). Perhaps, the commonest example is the lexeme رهبة (fear) found in the Prophetic saying reported by Al-Baraa Ibn Azib (may God be pleased with him) in the section of invocation الدعوات: "I resort myself to You out of wish and fear رهبة of you". Al-Bukhari said in Fath Al-Bari: 'wish means: seeking your bless and reward" رهبة / fear is fright of your anger and punishment. The author of النهاية في غريب الحديث Al-Nihaia fi gharib Al-Hadith said الرهبة means: fear and panic (Ibn Al-Atheer,1979)

In sahih Al-Bukhari and in sahih Muslim, The Prophet's Hadith (saying) reported by Jabir (may God be pleased with him) relates: "I was granted five things never given to anyone before: I gained victory depending on terror/horror for a month's walk ..." From the above discussion, we notice that the word الارهاب (terrorism/frightening) refers to the meaning of fear, fright and timidity. In The Qur'an and in The Prophet's tradition (Sunnah), however, it has a different meaning. The word رهب and its family denote a slight degree of fear. Rather, it means fear mixed with love, awe and submission. Some derivations of it also refer to ascetism and devoting oneself to worshipping, as well as abstention from worldly occupations and joys. This is in all verses or chapters.

By looking at the meanings and derivations of the Arabic word الارهاب (terrorism/frightening) in Arabic, Qur'an and in The Prophet's tradition (Sunnah), we can formulate a definition of الارهاب in Islamic vocation as follows: "It is a state of ascetism and devoting oneself to worshipping and awe from Allah happening to a person, in addition to being an action for frightening blasphemes hostile to 
Muslims and fighting them with the aim of stopping them from fighting or killing Muslims; it is not an action aiming at damage, destruction or sabotage. either with or without justification.

From this definition, we notice that:

- $\quad$ الرهبة (fear) in vocation(preaching) is a kind of devoting oneself to worshipping and awe from Allah.

- (terrorism/frightening) is a degree of fear intended to stop blasphemes hostile to Islam from attacking and fighting Muslims.

- الارهاب (terrorism/frightening) in Islamic vocation does not aim at murder, destruction or sabotage, either in souls or in properties, as this is viciousness and Allah does not like viciousness.

- We notice that the concept of- الارهاب (terrorism/frightening) in Islamic vocation differs in purpose and means from that in Western concepts.

\section{Causes and Motives of Terrorism}

The factors and motives of terrorism arise from psychological, intellectual, economic and social causes:

\section{First: Psychological Causes}

These mean the psychological traits an individual acquires from his surrounding environment. Failure in family life is considered one of the most important causes leading to the deviation of individuals and their acquisition of violence.

1. The love of celebrity and fame: Here an individual is not qualified so he seeks whatever makes him a hero before himself.

2. Frustration is the person's feeling of disappointment about attaining his due rights or getting what gives him benefit and comfort. (Al-Zahrani, 2004)

3. Study Failure: This makes an individual have a feeling, which makes him feel rejected by the society. This leads him to committing terrorist actions. (asSadlan, n.d. :p.n)

\section{Second: Political Causes}

1. Political Frustration: It results from the suppression some countries impose through their security systems against moderate Islamic groups and others.

2. The ruler's neglection of improving the economic and social situations of the society addition to not caring about the youth or communicating with them.

3. Secret parties which have resulted from wrong readings and concepts unknown to scholars. Allah (Glory be to Him) said in Al- An'am (The Cattle) 
chapter: "Surely you do not belong to those who were separated in religion and became different parties."

4. Imperial hegemony: when countries fostering terrorism destroy the economics of small countries and disturb security there by training and supporting terrorist groups.

5. Despotism and Tyranny: Despotism results in violating rights, minds, thoughts, dignity and shares in citizenship with its responsibilities. These gradually cause a bad change.

\section{Third: Intellectual Causes}

1. Depending on sources other than those of Islamic vocation as yardsticks or norms, such as deviant human minds and futile dialectic or reasoning philosophies.

2. Ignorance of Islamic rules, morals and ethics. Allah's Messenger (peace be upon Him) said: "Allah bestows Islamic knowledge upon those whom $\mathrm{He}$ wishes good." (Al-Bukhari, 2002).

3. Ignorance of the aims of Sharia (Islamic Law) and not conceiving them well: Here Allah (Glory be to Him) says in Al-Nahl (The Bees) chapter (verse:116): "Never utter with your tongues false sayings to say this is allowed and this is forbidden, telling lies about Allah; for those who tell lies about Allah are never successful". Exaggeration heralds hastily say forbidden without restraint with the motive (reason) of piousness. This is what was done by Khawarij (dissedents) as they rebelled against religion, just as an arrow flies out of the bow. That is because Allah's Messenger (peace be upon Him) said: "They read The Qur'an without its reaching their chests (Al-Bukhari,2002). The meaning is that they do not comprehend The Qur'an so that it can reach their hearts.

4. Exaggerative thought: it is going beyond limits. Allah's Messenger (peace be upon Him) said in Sahih Muslim: Ruined are those who exaggerate. He said that three times. Those are people who are stern and go beyond limits in their sayings and doings (Abu Dawud, 2009)

5. Young people's taking knowledge from each other without referring to scholars-Ibn

mas'oud says (from the Prophet): "people are still in good as long as they take knowledge from their great and honest scholars, but if they take from the petty and the wicked, they will be ruined." (al-Qurtubi,1994)

6. Charge of unbelief: resorting to Charging others of unbelief for merely having different opinions. Allah's Messenger (peace be upon Him) warned against that. He said: if a man Charges his fellow of unbelief, then either of them will be unbeliever." 
(Al-Bukhari, 2002)

7. Misunderstanding texts and seeking the ambiguous: Aisha (may God be pleased with her) said: Allah's Messenger(peace be upon Him) recited this Qur'anic verse: "It is He (Allah) who revealed to you the book including wise verses, these are the mother of the book (Al-Fatiha) and other are ambiguous/those having aberrant hearts seeking the ambiguous verses for the sake of unrest and for interpreting it falsely. Solely Allah knows its interpretation/ those who are truly knowledgeable say: we believe in it; for it is entirely from God; only the wise do remember that", then she said: Allah's Messenger (peace be upon Him) said (if you see those who seek the ambiguous verses, then those are whom Allah mentioned, so beware of them.) (al-Bukhari,2002).

8. Laziness of scholars about performing their duty: this was a motive for the appearance of those extremists to give people opinions about the legal and the forbidden, then terrorism takes place. Allah (Glory be to Him) said in A'li Imran chapter: "And when Allah took the pledge of people of the scripture, saying make it clear to people and do not conceal it, then they left it aside and sold it for a petty price; what a bad price it is."

\section{Fourth: Economic Causes}

There is an equation saying: Ignorance + poverty + suppression, dictatorship, exclusion and inattention = destructive terrorism. Some_economic phenomena causing terrorism can be outlined as follows:

1. Underdevelopment: This is the case of unsuitableness of economic policies to the social reality individuals live; thus there are vast gaps between the classes of the society.

2. Unemployment: it plays a great role in spreading terrorism and violence, as individuals feel irresponsible and that they have nothing to care or worry about.

3. Lack of social justice: This is the lack of equal division of basic needs among groups of the society, and not providing these for them. The oppressed group feels social injustice; this leads them to revenge.

4. Administrative and governmental corruption: These practices create in the deprived youth a violent aggressive behavior, which results in armed terrorist actions represented in the instances of ravage, plundering and planned kidnapping actions.

\section{Fifth: Social Causes}

1. Contradictions in peoples' and the dissimilarities they find between what they hear and what they see. There are often usually great contradictions between what a person reads and what he sees, what he learns and what he 
experiences, what is said and what is done, what he is taught and what he sees. This causes a disturbance in conceptions and a perplexity in notions.

2. Lack of coherence/relation among individuals of the society makes a person feel irresponsible towards it and think only of his desires.

3. Leisure: Allah's Messenger (peace be upon Him) says: (There are two blesses that many people do not appreciate: health and leisure." (alBukhari, 2002). Leisure is a cause of man's wickedness and loss of Religion.

\section{Facing Terrorism in the Light of the Values of Islamic Preaching}

Islamic vocation, through its two main sources: The Qur'an and the prophet's tradition (Sunna), has treated whatever leads to terrorism by treating its causes:

1. Stubbornness: The vocation faced this, which is the obstinacy in questions and problems arousing suspicions in hearts. That is through Allah's saying: (Oh you who believe never ask about critical matters whose exposition will trouble you; if you ask about them on the revelation of The Qur'an, they will turn out to be forgiven by Allah/ Truly Allah is All Forgiving, All Enduring (AlMaidah (The Table) chapter 101). Allah's Messenger (peace be upon Him) said in/ sahih Muslim: Ruined are those who exaggerate. He said that three times. Those are people who are stern and go beyond limits in their sayings and doings (Abu Dawud, 2009)

All texts of both The Qur'an and Hadith thus aim at following the approach of facilitation, lightening and refusing sternness and extremism in the subtle details and issues so that facilitation does not become difficulty, which Allah warned against in Al-Haj/ pilgrimage chapter: 78(Struggle truly for the sake of Allah /He preferred difficulty and never imposed any difficulty on difficulty in religion /This is the creed of your forefather Abraham.

2. Zealotry/sternness: This is the inclination towards the contrary of lightening and facilitation. Anas Ibn Malik related that Allah's Messenger (peace be upon $\mathrm{Him}$ ) said: "Never be stern to yourselves so that Allah will not be stern to you; for once some people were stern to themselves, so Allah was stern to them, there are their ruins in worshipping towers and houses. That was a monasticism which they created and which Allah did not impose on them. (Abu Dawud, 2009)

Allah's Messenger (peace be upon Him) refused the action of his companions who exaggerated in_worshipping and ascetism far beyond moderation and modesty. Anas Ibn Malik related that three people came to the houses of the Prophet's wives to ask about the worshipping of the Prophet (peace be upon Him). When told about that, it seems they did not admire it. They said we are no parallel to Allah's Messenger whose previous and coming sins Allah had forgiven.one of them said: I pray all night long. Another said I fast 
continuously without breakfast. Another said I abstain from marriage. Allah's Messenger (peace be upon Him) came to them and said: It is you who said so and so? I swear by Allah I am most pious and fearful to Allah. Meanwhile, I mix fasting and breakfasting, praying and having rest, and do marry women; so whoever refuses my tradition is not a follower of mine. (al-Bukhari, 2002)

3. Seeking Difficulty This means making difficult what is easy. Allah (Glory be to $\mathrm{Him}$ ) said in Al-Baqarah (The Cow) chapter: "Allah wants easiness and not hard ship for you. The Prophetic general commandment came about moderacy, modesty and not seeking difficulty in religion. Abu Hurairah (may God be pleased with him) related that Allah's Messenger (peace be upon Him) said: religion is easiness and whoever exaggerates in it, will be beat/defeated by it.so be modest and easygoing and use the help of active pursuit of work, in early morning and in the evening sometimes. (al-Bukhari ,2002)

4. Exaggeration in religion: warning against Exaggeration came when Ibn Abbas related that Allah's Messenger (peace be upon Him) said: Beware of Exaggeration in religion; for your forefathers were ruined by Exaggeration in religion. (Ibn Hanbal, 2001) Also Allah spoke to the people of the scripture in Al-Nisaa (Women) chapter, saying: "say Oh people of the scripture never follow Exaggeration in your religion saying what is not right, and never follow the whims of people who were mislead before and mislead many others and deviated from the right path." From these verses, we have to be careful to correct our belief (fath) in the light he Qur'an in The Prophet's tradition (Sunnah) Without neglection or Exaggeration in religion. Allah's Messenger (peace be upon Him) warned of that in his saying: This religion is strong, so go further in it gradually, unlike a man lost halfway between two destinations. (Ibn Hanbal, 2001)

From the practical view, Islamic preaching has laid several Qur'anic and Prophetic educational values for facing terrorism, including:

1. The value of leniency and justice among humans, without discrimination among them because of race, religion, or ethnic group. Allah's Messenger says: Allah is lenient and likes leniency and rewards for leniency more than violence and more than any other thing (al-Baihaqi, 2003).

The Prophet's tradition was the model and example. For instance, Aisha (may God be pleased with her) related that: a group of Jews came in at The Prophet's and said السام عليكم (death be unto you). Aisha said: I understood it and said: the same to you and damn you. (السام resembles السلام,meaning: peace) Allah's Messenger said: Hey, Aisha, Allah likes leniency in all matters. In another narration, he said: beware of violence and impoliteness-I, Aisha, said: Oh Allah's Prophet, didn't you hear what they said? Allah's Messenger said: I have said: the same to you. (Al-Bukhari,1424H). 
2. The value of mercy with wrongdoers: Anas Ibn Malik related: " while we were in the mosque with Allah's Messenger, a Bedouin man came and urinated in the mosque. The Prophet's companions said to him: stop it, stop it. Then Allah's Messenger said: Don't trouble him. Let him off. Then they let him finish urinating. Then Allah's Messenger called him and said to him: These mosques are not place for this urination or filth. Rather, they are for worshipping Allah, prayer and reciting Qur'an. Then Allah's Messenger ordered one of the men to bring a bucket of water, so the man spilt it on the filth. (al-Arnaout ibn-alathir-1972) Here, Allah's Messenger settles the situation most leniently(gently) as he stopped his companions from violence with the wrongdoer. He taught a lesson quietly and gently, without frightening or terrorizing.

3. The value of moderacy and modesty: Allah (Glory be to Him) said in AlBaqarah (The Cow) chapter:" Thus we did make you a moderate_community to be witnesses about people and so that The Prophet' will be a witness about you/ verse 143" Abu Hurairah(may God be pleased with him) related that Allah's Messenger (peace be upon Him) said: religion is easiness and whoever exaggerates in it, will be beat/defeated by it.so be modest and easygoing and use the help of active pursuit of work, in early morning and in the evening sometimes. (al-Bukhari,2002)

4. The value of peacefulness among individuals of th society: Jabir related that a man came to Allah's Messenger and asked: "Oh Allah's Messenger, which Muslim is the best? The Prophet replied: A Muslim is the one who is peaceful to Muslims in his sayings and doings.(al-Bukhari,2002)

5. The value of forbidding violence with women and servants: The Prophet emphasizes a set of orders and prohibitions that prevent violence in the society and spread the spirit of love and mercy. Here is Allah's Messenger saying "Never beat Allah's she-servants. Then Omar came and said: They have been disobedient to their husbands.so the Prophet gave permission of beating them. Then many women came repeatedly to The Prophet's household to complain about their husbands.so the Prophet said: many women came repeatedly to The Prophet's household to complain about their husbands. These are not the good men among you (Abu Dawud, 2009). Allah's Messenger also prohibited violence with women and servants. When Abu Mas'oud Al-Ansari beat one of his boy servants, The Prophet said: mind you, Abu Mas'oud, Allah's might on you is greater than yours on the boy". Abu Mas'oud said: I turned and saw Allah's Messenger So I said: "Oh Allah's Prophet, I set the boy free for Allah's sake. The Prophet Said: weren't you to do that, The hell would torment you. (Abu Dawud, 2009).

6. The value of forbidding killing and shedding blood: Allah (Glory be to Him) did forbid killing. In Al-Esraa chapter, Allah says:" Never kill the souls that Allah defended except for a legal reason". He made that one of the major 
sins. Allah's Messenger also emphasized the greatness of this crime, to repel persons from committing it, saying: Were all population on earth and in heaven to share in killing a believer, Allah would throw them into Hell (alTirmidhi, 1975).

He prohibited whatever can horrify people. Allah's Messenger (peace be upon Him) said: whoever waves to his brother, even to his sibling, with a rod of iron, will be cursed by angels (al-Nisaburi, n.d.)

7. The value of prohibiting causing fear: Allah's Messenger prohibited frightening others, even with the aim of kidding. Abdel Rahman Ibn Abi Leila related that they were walking with Allah's Prophet. Then one of them fell asleep. Some of them. So some of went to take a rope which was with the man so he was frightened. Then Allah's Messenger said: A Muslim is not allowed to horrify any other Muslim (al-Baihaqi, 1994).

Islamic vocation has laid several legislations to confront the wicked, such as the punishment called retaliation/revenge and the punishment of infringement (tyranny) and that of bullying/burglary. Allah (Glory be to Him) said in Al-Mai'da (Table) chapter:33. "Truly the punishment of those who wage war on the law of Allah and his Messenger and spread tyranny on earth is that they be killed directly, be crucified, have the hands and legs cut off conversely, or be banished. That is a shame for them in the wordly life and agreat punishment awaits them in the afterlife. That is because the matter is related to the safety and security of the society.

8. The value of pursuing easiness and removing hardship in Islamic vocation: Abu Mousa Al-Ash'ari said: it was the habit of Allah's Messenger when sending a companion of him on a mission to say: convey good omens, not bad omens and follow easiness, not hardship. (al-Bukhari,2002) Allah's Messenger also said: Leniency always beautifies matters and violence always deforms them (al-Baihaqi,2003). He also said: Allah is lenient and likes leniency in all matters and rewards for it more than violence (Al-Bukhari). In the literature, The Prophet says: no one should preach in good and evil except someone prudent in his recommendations, lenient in them and gentle in them. (al-Muslah,1421H)

\section{Conclusion}

1. Asserting that Islamic vocation (preaching) is not part of the problem of terrorism. Rather, it is a strong basis and an effective means for the remedy of its causes and putting an end to it according to the divine criteria through implanting the values of tolerant Islamic preaching. These call for not terrifying individuals or groups or 'frightening' them, or even doing them harm in any way threatening their wealth, their individuals or social rights or 
their lives. Terrorism cannot be ascribed to Islamic vocation which is a divine message coming for achieving security for both individuals and the society.

2. That facing terrorism necessitates implanting the values of tolerant Islamic preaching which is far from bigotry \{fanaticism $\}$ and extremist interpretation that gives texts undue interpretations.

3. Also the philosophy of Islamic vocation aims essentially at building a social structure caring for relating the individual to the society through solidarity, love and belonging in order to keep the stability of the society.

4. That terrorism cannot be ascribed only to the religious factor, for there are other factors which may be more important than the religious factor such as poverty, unemployment and misunderstanding religion.

5. The research has pointed out the danger of the misuse of modern technology and electronic means of technology as this contributes greatly to spreading and growth of the phenomenon of terrorism.

6. The research has proved that the phenomenon of terrorism is a phenomenon which is Christian and Zionist rather than one related to Islam

\section{Recommendations}

1. Arbitration of the law of Islamic call in the lives of Muslims, and the achievement of justice and balance in life.

2. Must be interested in the development of the Muslim on the basis of the Islamic call of faith contract; re-reworking of souls, and open the horizons of minds, and broadcast the spirit of genuine advocacy.

3. Dissemination of the middle prophetic culture between Islamic and non-Muslim societies, and immunization against intellectual invasion.

4. The Islamic call should be preceded by scholars who are characterized by mediocrity and a tolerant approach.

\section{Corresponding Author}

Moustafa Hassan Al-Khaiat, Faculty of Contemporary Islamic Studies, University of Sultan Zainal Abidin

\section{ACKNOWLEDGEMENT}

Special appreciations to the Research Management, Innovation \& Commercialization (RMIC), University of Sultan Zainal Abidin (UniSZA) for sponsoring the project.

\section{References}

Al-Albani, A.A. (2002). Saheeh al-Imam al-Bukhari. Riyadh: Al Ma'aref Library for Publishing and Distribution. 
Al-Arnaout, A.Q. - (1972). The Mosque of the Fundamental Principles in the Prophet's Hadiths. Lubnan: Dar Al-Bayan Library.

Al-Muslah, K.A.M. (1421H). Explanation of the Doctrine of Al-Wasitiyya from the words of Shaykh al-Islam Ibn Taymiyah. (Ed.) Dar Ibn al-Jawzi. Dammam, Saudi Arabia.

Al-Sadlan, S.G. (n.d.). Causes of Violence, Terrorism and Extremism / Edam Ghanim Saleh bin Al-Sadlan, Imam Muhammad bin Saud University 12.

Al-Tirmidhi, M.I. 1975). Sunan al-Tirmidhi, Egypt: Mustafa Al-Babi Al-Halabi Library and Printing Company.

Al-Zahrani, N.M, (2004). Harvest of Terrorism, Riyadh-Saudi Arabia, Obeikan Library.

Az-Zouzi, H.B.I. (2004). Issues of Terrorism, Violence and Extremism in the Balance of Quran and Sunnah. Scientific Committee of the World Conference on the Position of Islam on Terrorism.

Ibnal-Atheer, M.D. (1979). The end in the strange talk and impact. Beirut.

Ibnhanbal, A.A. (2001). Musnad Imam Ahmad bin Hanbal. (Ed.) Investigator: Shoaib Arnaout - Adel Murshed. Al-Resala Foundation.

Ibnmanzoor, M.M. (n.d.). Lisan al-Arab. Beirut: Dar Sader.

Ismail, S.I. (1423H). Questions about Islam and comments. Association of the Islamic world.

Khairuldin, W. M. K. F. W., Anas, W. N. I. W. N., \& Embong, A. H. (2018). The Binding of Laws to Personal Opinion of Muftis in Malaysia. International Journal of Academic Research in Business and Social Sciences, 8(11), 522529.

Khairuldin, W. M. K. F. W., Anas, W. N. I. W. N., \& Embong, A. H. (2018). Fatwa as a Disseminator of Islamic Laws among Community of Malaysia. International Journal of Academic Research in Business and Social Sciences, 8(11), 516521.

Khairuldin, W. M. K. F. W., Embong, A. H., Anas, W.N.I.W.N., Mohd, H. \& Ismail, D. (2018). The Application of Technology in the Dissemination of Fatwas: A Study on Religious Institutions in Malaysia, International Journal of Civil Engineering and Technology, 9(7), 2018, pp. 1590- 1596.

Nuclear, Y.S.A.Z. (1996). Explain the nuclear on a Muslim, Dar al-Khashreena Publishing.

The Arab Convention for Combating Terrorism, signed in Cairo on 22/4/1998, Law No. 57 issued on $31 / 3 / 19$, p 